Marek Krawiec, Ph.D.

Academy of Management

\title{
FROM DIRECTIVE GUIDANCE TO MENTORING
}

\section{Introduction}

This paper aims at presenting the practical approaches to chosen forms of support of self-reliance gaining process of young people coming from different forms of foster care. The most important forms of support include vocational counselling practiced during the realisation of the following projects by the Academy of Management in Lodz in the period of 2004 - 2012:

- The EQUAL Community Initiative project "Leaving Children's Homes New Chances, Better Tomorrow" realised in a national and an international partnership (2004 - 2008).

- "Development Support Centre as a tool of vocational and social integration of youths endangered with social exclusion" implemented within measure 7.2.1 of Human Capital Programme co-financed by the European Social Fund (2008 2009).

- "Development Support Centre" implemented within measure 7.2.1 of Human Capital Programme co-financed by the European Social Fund (2010 2011).

Vocational counselling, used in this case as one of the tools supporting the process of gaining self-reliance by the pupils from children's homes (and later also from other forms of foster care), was not always directed at youths. In two projects, there was also a slightly different target group - pupils from children's homes cooperating with the Academy of Management in realisation of the EQUAL project, and volunteers trained to be mentors for the beneficiaries of the last realised project: "Development Support Centre".

A chosen group of educators from children's homes, cooperating with the Academy of Management in realisation of the EQUAL project, took part in postgraduate studies on vocational and social guidance. These complex (940 hours in total) two-year long studies were a chance not only for learning the guidance but also for using the gained knowledge, competencies and skills later in work with 
their pupils, still during the education. It can be stated that for the students these four semesters of studies were an experience of participating in a long counselling session - after graduating (and in some cases during the studies) $25 \%$ of the participants made autonomous decisions of changing their jobs. In a sense, this was also one of the success indicators of this undertaking.

In the second case - basing on the mentor and peer mentor education path for groups endangered with social exclusion (Sołtys, Tarkowska, 2008), prepared during the realisation of the EQUAL Community Initiative - the applying volunteers were prepared to taking on the role of mentors during a long, extended training. The training lasted from May to December and included distinct elements of vocational counselling (knowledge of professions, career information). This role was played also by a series of supervision sessions for the mentors, organised during the period of their work with the pupils.

The thesis included in the title - from directive guidance to mentoring - does not imply a preference of the linear or the parallel vocational processes. The linear image is relating to guidance and its directive forms still being in the process of change, shifting towards chosen models of contemporary understanding of guidance as a lifelong accompaniment (Paszkowska, 2008 after: Lamb, 1998, Gęsicki, 2004) - including coaching and mentoring. The parallel process of counselling indicates realising simultaneously the classical guidance - in its directive form and its modern forms, such as mentoring.

An analysis of guidance activities realised in the mentioned projects gives an image of both linear and parallel counselling - although the image of the parallel guidance is much more visible.

The intention of the author of this paper is that the reader, by analysing the described counselling processes in the realised projects, can judge and decide on the predominance of one or the other type of guidance, or recognize the need to make that choice as a false dilemma.

Before a description of the specific counselling strategies implemented in the projects is presented, it is necessary to address the key concepts of this study - vocational guidance (or counselling - the author treats both of these terms interchangeably and equally, unwilling to engage in theoretical disputes which do not add anything special to the basic problem of this presentation) and coaching with its particular form that is mentoring (Parsole, Wray, 2002, Sołtys, Piekarska, 2008).

The modern approach to counselling emphasizes the extension of its mission by placing counselling as a permanent component of lifelong learning. It is no longer a clearly individualised form of activity performed by vocational counsellors, psychologists and pedagogues supporting career decision-making processes in the comfort of their offices, or even, in more modern models, during group meetings or school classes, or in other circumstances. This approach results in the emergence of two major challenges (Krawiec, 2007): 
- The need to transform vocational guidance from activities aimed at helping students in making career decisions, to actions leading these students to acquire skills of independent career management;

The ability to build and develop ones own competencies, and finally to manage them, is the basis and the determinant of career and life (family, social) success, definitely differentiates the income, the positions in social structures, and the placement in the organisational hierarchy. The development of these skills is now the subject of the European Employment Strategy.

- The need to take action of increasing the availability of vocational guidance for the entrants to the labour market, workers and students, in particular the representatives of disadvantaged groups, the excluded, or the ones at risk of social exclusion;

The situation in Poland today is that the use of these services is easier for the unemployed and the students, although, as it was mentioned before, generally these are not the services that help to shape the career in the wider meaning. In addition, the vocational counselling for adults (less than for young people) is mostly performed during realisation of specific projects, and in practice is often used for selection for trainings, or for participation in certain social events. Perhaps the basis of this state are the problems in defining the expectations towards modern systems of information and vocational guidance - in fact, this has been made clear in few countries so far (Grubb, 2002, Krawiec, 2007).

Career guidance for young people entering adult life, including the ones from children's homes and other forms of foster care, who are involved in the process of gaining self-reliance, is generally implemented through counselling services offered by schools (mainly psychological counselling offices and school pedagogues), and also as a part of work performed by the Voluntary Labour Corps, and occasionally by vocational counsellors in the District Employment Agencies, or by the staff of the Centres for Information and Career Planning of Voivodeship Employment Agencies and their branches. Sometimes there are vocational counsellors working directly in institutions or schools - but such cases are very rare, or the vocational counsellors who possess appropriate competencies are able to provide their services in a very limited way.

The vocational counselling services are also offered by other entities - training facilities, District Employment Agencies, NGOs, as a part of their ongoing social projects (training, education) - but one has to remember that these projects mostly serve the implementing of the state social policy which does not always meet the individual needs their beneficiaries.

Changes taking place in vocational guidance in Poland, and around the world, relate to changes that societies are going through during their turbulent development in recent years. Career guidance has been successfully adapting in the $60 \mathrm{~s}$ and the 70 s to the needs of the industrial society, in the 80 s to the service society, 
and in the 90s to the information society - and today, in the twenty-first century, to the Web society (Kargulowa, 2005).

Vocational counselling is frequently equated with career guidance, and often these terms (like in this study) are used interchangeably. Typically, vocational counselling is seen as a social process that takes place within an interaction of two entities, and its characteristics are:

- voluntariness,

- meeting of entities,

- dialogue.

Thus, in this interpretation, the aim of vocational counselling is helping a person in achieving self-reliantly the maturity, the courage, and the critical approach in making choices and assessments. A significant part of this interpretation of vocational counselling is the fact that the decision to ask for advice, and the way of using it, are a result of a self-reliant choice. (Czerepaniak-Walczak, 2001)

Counselling can also be adapted to a mass scale and carried out by providing advice, information, or instructions, by the means of mass communication. In this perspective, its directiveness becomes more apparent - derived from managing, convincing, preaching, and persuading, that result from the strong advantage of competencies of the counsellor over the client's. (Małecka, 2004)

When it comes to the perspectives of guidance, in 2004 the European Council accepted a resolution concerning lifelong vocational counselling, which stressed the need for empowerment of the institutions creating and implementing political, legal and system solutions on national and regional levels. An attempt was made to build structures for implementation of the decisions made in the mentioned resolution by establishing a Lifelong Guidance Policy Network. All EU countries declared to participate in the work of the Network, including Poland. New challenges for European (including Polish) vocational counsellors led to the evolution of their activity, often described as vocational euroguidance or lifelong career guidance. It is one of the key actions of the Lisbon strategy directed towards building a European identity and eliminating unemployment.

Finally, it is important to note that what really is making the changes occurring in career guidance visible, is its reorientation towards the recipient of those services, the real client.

The focus on the client evokes a strong interest in the recipients at different stages of life - not only the ones entering the labour market or making important educational decisions. The area of interest contains not only the career problems, but the overall life situation of the client, and the development of skills of selfreliant career management. It is also assumed to go beyond the specified groups of recipients (for example, certain risk groups), and to include the people from these groups in the mechanisms, procedures, and guidance methods. 


\section{New Forms of Guidance - Coaching and Mentoring}

The new approach will be visible in creation of service quality assessments, and in new forms and methods of counselling. The last decade brought a lot of new tools and techniques of counselling. A significant revolution happened even earlier - the primacy of the restrictions was replaced with the primacy of resources; for example, through the ideas of the so-called Spanish method, guidance became a process for the development, and not only leading to decision-making. Methods of group work with customers are being used more frequently; coaching and mentoring are becoming increasingly more important. The former is mainly used to support and develop professional skills, often by discussing personal matters. It excludes guiding the client towards the "right" solution, or advising anything, and focuses on accompanying the client in discovering their own resources, supporting, motivating.

On the other hand, mentoring means using ones own experience and skills in supporting the client's actions, who often has a similar (or the same) social background. This method is being included more and more often in the counselling practices, especially when working with excluded groups, or the ones endangered with exclusion. Because of its place in the guidance practice realised in the mentioned projects and the main thesis presented in the beginning of the article, it is analysed more thoroughly.

The idea of mentoring has been developing gradually since the 80 s as one of the effects of popular demands for more personalised forms of work with individuals and groups at risk of development stagnation. The growth of this idea was made possible thanks to including the objectives of mentoring in the scope of the pursued and promoted social policy demands (mainly in the UK and the US). Today, mentoring is considered the intellectual and social revolution of the methods of working with people - effectively replacing the institutional, somewhat rigid, hierarchical procedures of supporting development and individual or group changes. The individual work method allows neutralising the negative effects of the traditional forms of support based on an instrumental, often directive approach towards the client, frequently limited to defining his/her status, and responding formally in accordance with the procedures, rights and obligations prescribed to this particular state of affairs. The method of mentoring guarantees by assumption that the clients do not experience the feeling of losing control over themselves and the institution, because they are involved in defining the work plan and the objectives, and are co-responsible for the effects. Engaging and stimulating the client to achieve tangible results overcomes the attitude of learned helplessness, and the feeling of meaninglessness and lack of influence on their own lives or achieved results. The client copes more easily with the state of frustration and aggression resulting from, for example, the inadequacy of 
possibilities and expectations. Positive aspects of individual work are measured by an increase in knowledge and competencies, first successes, acquisition of the ability to assess the environment and its expectations towards the individual properly, and on the other hand, the increased efficiency of the institutions - the client becomes self-reliant and self-steering, more effective in life, and in result does not require further engagement of resources from the institutions (time, money, people), or starts to achieve tangible benefits (increased productivity, better performance, and financial success).

Mentoring and coaching are a kind of a hybrid response (Sołtys, Piekarska, 2007) to the problem of working on the effectiveness and potential of a person, and thus had to develop methods of work which include patterns, tools and standards modelled on those areas in which the development, effectivity, potential, change and improvement are both the starting point and the ultimate goal.

There is no doubt that the genesis of the idea of mentoring is related to the academic influence and output, especially in the field of management, the concepts of process re-engineering, total quality management, improvement of customer service, the idea of a learning organisation, or management of knowledge and intellectual capital of the company. "A learning organisation harnesses the full power of the mind and the available knowledge and experience to constantly evolve for the benefit of all of its shareholders." (Parsole, Wray, 2002, p. 27) The theoretical and practical output in the field of management science contributed to the promotion of the active attitude, involvement in the decision-making processes, increasing the self-reliance and responsibility of people whose potential can only be activated by increasing their autonomy and sense of subjectivity, which is also the key to organisational, economic and personal success. Of course, a basic fact cannot be omitted - that the science of management has its roots in the social psychology and the psychology of work.

Sport is undoubtedly another area of experience derived from effective personal work with individuals and groups. It is a rich source of the most spectacular evidence that success results from the quality of the "overall" work of the coach (starting with the belief in the possibility of training "great coaches" able to achieve the "unprecedented results", the border of the set requirements, the mastery in motivating and asking questions, the ability to provide and receive feedback, the use of the PDP model (personal development plan) and GROW (goal, reality, options, will), and the potential and work of the player). The common element is creating a need for a person who, through their knowledge, experience and commitment to the development of the pupil, is able to guide him/her through changes which form the basis of his success (in sports, in career). And such perfect coach "...is fully committed to the work with the pupil, and that kind of relationship can be compared to a dance between two people, in which harmony and partnership are the most important" (Parsole, Wray, 2002, s. 48). 
Mentoring and coaching refer also to the experience of psychotherapists and vocational counsellors who define themselves as experts in "helping people solve personal crises or cope with too strong stress" (Parsole, Wray, 2002, p. 15), or as co-participants of consciously pursued path of development. The result of combining of these experiences is the development of standardised and certified professionals - business coaches and mentors working generally on commission for large corporations. The rules of work are taken from the psychotherapeutic work rules, and applied to "training" sessions during which all the tools of working with a client are used (personality profiles, feedback, etc.). "The problem of these people - bosses, CEOs, leaders - lies in the fact that they always have to be in shape (...) Because they are ambitious, they constantly ask themselves a question: I'm good, but can I get even better?" (Pomocnik psychologiczny, Nr 47 (2581), 25.11.06, s. 36).

Another component of the modern image of mentoring and coaching is the influence of the trend called "new life" which includes exploring ones own personality, performing formally attractive trainings from the field of management and interpersonal relations, using the practical and theoretical output of the Gestalt school, transactional analysis, neuro-linguistic programming.

Mentoring and coaching are usually defined as modern forms of individual work with the client (ward), aiming to support his/her growth and to gain success (in life, society, career, education), using tools inspired by the work techniques of sport trainers and practicing therapists, oriented at goals, active performance, and achievements. The key to success of these activities is the personal involvement of the trainer/therapist in the pupil's activities, supporting him/her, and taking into account his/her needs and potential.

For many researchers and authors (Parsol, Wray, 2002, Sołtys, Piekarska, 2007) the difference between coaching and mentoring is rather a semantic one, and practice shows that coaching is a practical form of support in business institutions, and as such is a form of mentoring that focuses on career and achievements (organisational sponsor), while mentoring refers to the sphere of social and educational activities, and is equivalent to supporting the development (personal development and learning are the aims) (Clatterbuck, 1998).

Eric Parsloe (1997) defines coaching as "a two-way process of helping to develop skills and achieve better results through a reliable assessment, focused practice and feedback", and perceives mentoring as "taking care of a worker in various stages of their professional development and of their career in the enterprise - from the moment of employment, up to reaching the position at the top". We now know for sure that these definitions need to be significantly expanded.

Mentoring developed as a form of support for individuals who had difficulties in adjusting to social requirements and expectations. This form of support, preventing social exclusion, is often called social mentoring - it has several versions and is being implemented on various institutional levels, often through 
various government social programs, or through social initiatives. Well known is the use of mentoring in the processes of education and in teaching workers, which is a part of Fair Deal at Work, promoted by the Government of the United Kingdom, aimed at help in finding a job, especially for the unemployed youth (or other groups - single parents), allowing them entrance into work life, and thus preventing social exclusion. The British Department for Education and Employment carried out the "educational mentors" project which gave employment to thousands of people working with students achieving poor results in education, and the Ministry of Internal Affairs supported mentoring projects aimed at persons at risk of involvement in drugs, alcohol, or other criminal factors (Soltys, Piekarska, 2007). The idea of these projects was based on a simple principle to prevent the socially unacceptable phenomena by supporting the groups at risk of maladjustment or exclusion, and fighting discrimination in all its forms. The largest British charities, such as Reiner or Princes Trust, have been implementing the idea of mentoring for young people leaving institutional care centres (children's homes, foster homes - in Poland, these are different forms of foster care). The idea of peer-mentoring is promoted as strongly in the UK. In Poland, it was used probably for the first time during the implementation of the EQUAL Initiative - "Children's Homes Pupils - New Chances, Better Tomorrow" (Krawiec, 2007). Most of the institutions implementing mentoring are developing their own manuals and training programs for mentors, although regular studies and training offers are available (Academy of Executive Coaching, Oxford School of Coaching \& Mentoring, Oxford Brookes University, School of Coaching at the Industrial Society), which shows, of course, that another step in the process of institutionalisation of support and counselling was taken, exactly in accordance with the definition: "a direct relationship of unappreciative nature, in which a person voluntarily devotes their time in order to support (encourage) the other person in a special period of change of the pupil, and lasting for a significant period of time". In Poland, during the aforementioned EQUAL program, a certified path of training for mentors dedicated to support young people in the processes of gaining self-reliance was created (Soltys, Tarkowska, 2008, Krawiec, 2007).

In the U.S., the practical realisation of the idea of mentoring can be seen in the introduced in the 80s and the 90s Puente Program - created to support the educational efforts of Hispanic students. The idea used in this program is based on the work of the counsellor playing here the role of a mentor and a counsellormentor liaison. Such person is usually recruited from the local community (Latin American). His/her tasks include assistance in diagnosing the school problems, and developing measures to solve them, help with preparing students to take the school skill tests, and above all, together with other professionals, construction of individual career paths (Grubb, 2002, Krawiec 2006). 


\section{Mentoring and Peer Mentoring in Working with Disfavoured Youths}

From the counselling performed during the EQUAL project, to the activities of the Development Support Centre funded for the next four years by the ESF (Human Capital Programme), mentoring was a particularly important tool in the counselling activities. Its participation in the processes of gaining self-reliance can be portrayed in three basic dimensions (types):

- peer mentoring,

- entrepreneurship camps,

- the 3rd type of mentoring.

This division is rather symbolic - in practice it is not definitive, the three types or dimensions interpenetrate each other, the proportion of mentoring is also different for the each phase (project) of the performed counselling.

1. The use of mentoring as a tool for supporting the effectiveness of self-reliance gaining process began with the implementation of a special kind of mentoring used in the UK - peer mentoring. In our reality (and also in British), peer mentoring was based on engaging older colleagues in working with the self-reliance gaining pupils - those colleagues who have successfully completed the process of becoming independent, or were in a stage that boded well. The main expectation here was the best possible knowledge of the pupils' environment, but also the individual features of the pupils, positive from the point of view of social norms and values. These features (among other things) allowed them to find themselves at this stage of the effective process of gaining self-reliance, and going into the independent living.

There was one other major reason for the high hopes associated with peer mentoring. Engaging people from the same background and at a similar age, with similar life experiences, practically guaranteed avoiding communication barriers appearing normally between pupils and people from the outside (adults, the independent). In fact, this assumption proved to be extremely accurate, but as it turned out later, it was not quite enough.

Thus, the first form of mentoring, peer mentoring, was carried out by the established Mentoring Office and its members - the independent pupils, or the ones in the final stage of gaining self-reliance. The office organised its work by making plans and constructing efficient ways of maintaining contact and helping their colleagues.

2. Another way (dimension) of participation of mentoring in the self-reliance gaining processes was the entrepreneurship camps. The idea was based on the assumption that all models, programs and instruments that were to be used for effective self-reliance gaining processes were not really effective without the active participation of the pupils. After all, in order for the actions aiming at gaining selfreliance to have a point, the pupils had to participate actively in them (compare: Gaś, 2000). It is obvious that this would be possible, if: 
- the program's target group knew not only the basic guidelines, but also all the opportunities they can gain from,

- the importance of personal, individual motivation for participating in the project was included,

- the participants were able to apply their own vision of participating in the project, based on their individual experience,

- the project in a sense "took part" in the educational process of its beneficiaries.

In order to achieve these conditions, it was decided to use the idea of camps - as a pretext for specific actions directed at the pupils participating in the project. Three editions of camps were planned:

- The first one - in a sense, it started the whole activity of the project directed at the beneficiaries - it was organised in summer 2005.

- The second one - in 2006, on one side it played the same role for the newly recruited participants, and on the other it was an opportunity for the most interested participants to develop further some of the agreements made in the first camp. During this camp, for the first time, the idea of mentoring was combined with the guidelines of an entrepreneurship camp - or in other words: using mentoring as a basis for organising and functioning of an entrepreneurship camp (Krawiec, 2007).

- The third, fourth and fifth ones were a developed continuation of the second camp with small modifications that did not change the main goals.

The experience gained during the first camp was the main inspiration for designing and modifying the plans for the next camps made in the beginning, and so it needs to be described in more detail.

Firstly, it was supposed to serve as a tool for accurate, reliable informing of pupils about the guidelines and possibilities of the project.

Secondly, it was supposed to equip participants with social competencies that are particularly important when entering into independent, adult life, especially interpersonal skills, knowledge of the basic possibilities of the surrounding social infrastructure, ability to work in a group, internalisation of the socially accepted norms and values.

Thirdly, it was intended to provide participants with the opportunity to spend their holidays surrounded by woods and water, away from the hustle and pollution of their environment.

Fourthly, it was supposed to be an opportunity to test the defined educational assumptions, with a particular emphasis on the preventive aspect (Gaś, Szymanska, 2000).

Building the camp's program was based on the procedures of constructing the early intervention programs (Gaś, 2000), taking into account the basis of professional psychological prevention (Szymańska, 2000), and also on the fundamental assumptions of the social rehabilitation methodology. Due to the specificity of the 
camp's participants, their number, and the characteristics of individual participants, prepared and provided by their foster care institutions, an adequate number of tutors was provided. Constant and direct care was provided by educators from the foster care institutions, who applied for participating in the project. The essential part of the camp's program was realised by the scouts at the age of about 20 years. Moreover, both groups were assisted by a group of volunteers - students, trainees, who not only helped in the supervision of the participants, but also gave their own additional ideas concerning the camp's program.

A very important aspect of the camp's functioning was "using" the participants' activity on a larger scale than it is usually done in this type of projects. When observing the daily functioning of the camp, it was visible that the number of conflicts between the participants, the participants with the scouts and the students, is much smaller than between the participants and the "professional" educators. In the final assessment, this type of organising supervision was evaluated as unfit for the objectives of the camp. Besides, it was quite a difficult experience for some of the "professional" educators.

The evaluation of the first camp allowed drawing conclusions and introducing some changes:

- The "professional" tutors and the volunteers were replaced with the selfreliant pupils, the participants of the first camp working in the mentoring office, active mentors, and even the participants of the first camp who were still in the foster care institutions, but who possessed some authority among their colleagues.

- These groups, together with the scouts, were prepared to perform the roles of tutors in a special training during which they took part in a professional course allowing them to work as educators at holiday camps. Moreover, they created a precise program of the camp in the form of concrete scenarios planning the whole predicted time.

The basic problem and the main guideline was organising the social relations at the camp in such way that even if they had an element of dependency, they still were mutually beneficial, also for all of the participants - which is in accordance with the standards of modern vocational counselling.

The applied organisational and educational solutions were based on the goals of mentoring (and peer mentoring also), being the effect of a search for the best methods of cooperation between a teacher and a student - effective but still connected to the traditional types of bonding and interacting.

Basing the organisational and educational goals of the camp on the idea of mentoring was a risky task. The newly recruited tutors were only about 20 years of age, they quite recently had left the foster care institutions, had various types of relationships with other pupils. They were to be assisted by the scouts who were also young, but had some experience in working with youths. However, this also caused a certain problem - during the former camp, the scouts were realising some parts of the program, sometimes even played the roles of tutors by establishing the 
limits and demanding respect of the regulations - which could have had an impact on the quality of the relationships. Moreover, the experience from the first camp showed a quite strong aloofness of the participants towards some points of the program, sometimes evolving towards a strong opposition.

3 . The 3rd type of mentoring - it relates to working with the self-reliant pupils within the 2010 - 2011 project "Development Support Centre". After a few years of experience, the implementers of these projects came to deal with the increasingly visible signs of "wear and tear" - not so much of the ideas, as the mentoring practices carried out by a relatively homogeneous group of young people. On the one hand, they were not inclined to popularising the method among their potential successors - as though they were making it somewhat difficult for the new colleagues to engage in the work of the Mentoring Office. On the other hand, they limited their own participation in its activities. The reasons for the decreased mentoring activities were different - many of them needed to focus on their studies at the university, a number of them started their own families, the financial situation of some of them was in the way - their jobs began to absorb more time. The project implementers began to raise hypotheses concerning the impact of the too cursory preparation and the not careful enough selection of this diversified group of very young people. Young mentors themselves also began to formulate judgments, noticing that being at the start of an adult life they have relatively few "achievements" in life - they have not yet completed their studies, did not reach a suitable financial status, or planned living conditions. It was not about impressing younger colleagues, but rather about identifying the indicators of the defined and achieved life goals. Many of the mentors also mentioned their declining motivation to work.

Everything pointed clearly to the need of replacing the mentor team with a new one, and modifying the recruitment criteria and the ways of preparing the volunteers to work. Firstly, the circle of persons to whom the offer to participate in the project as mentors was sent was extended - instead of engaging only the younger pupils or the older independent ones, the offer was addressed to a much wider body - students of pedagogy and psychology, probation officers, social service workers. They were offered participating in the project through volunteering with all its legal characteristics.

Secondly, a new way of selection was introduced - an interview during which all those willing to work in the project presented the strength of their motivation, the reasons for which they wish to participate in the project, their social and economic situation, and even their life and career plans.

Thirdly, basing on the certified learning paths for mentors and peer mentors (Sołtys, Tarkowska, 2008) developed within the EQUAL project, a training program was created - rich in content and relatively stretched in time - which was also a test of motivation for the candidates, and a test of the project implementers' ability to replace the candidates in case if anyone resigned from the project during the training. The training program contained four basic modules: 
- contact in the situation of giving help,

- communication between a mentor and a pupil,

- family context of a pupil in the work of a mentor,

- difficult situations in the relation with a pupil, lasted for 96 hours in total for each participant, and was realised within twelve days, during a period of six months.

Fourthly, the mentors were provided with professional supervision sessions conducted by experienced trainers perfectly acquainted with the pupils' environments.

Thus, mentoring is understood in our projects both as a tool used in career counselling, as well as its special form - on the one hand, it is an effect of the counsellor's work (and the recommended way to increase the efficiency of the processes of empowerment), as well as a special type of the counselling process - in which the mentor acts as a guide and helps not only in the construction of individual career paths, but also offers assistance in solving life problems.

\section{"Classic" Forms of Counselling - a Description of Practice}

In this context, how does the "classic" vocational counselling, aimed at the disfavoured youth at risk of social exclusion, and realised in our projects, appear? In order to present it the right way, a wider context needs to be considered. This will enable understanding the situation of the guidance recipients, as well as the used methods and tools.

Young people, who are having a great difficulty in acquiring the educational basics, often displaying behaviour issues, sometimes coming into conflict with the law, are in a situation that requires a particular care on the part of both the educational, as well as the care system. It would seem obvious that these youths, staying under care of government, should receive from their caregivers a special support, especially in as important areas as education, entering the labour market, and professional development. It would seem that, while staying under care of specialists, they will be diagnosed accurately - especially when it comes to vocational predispositions and cognitive abilities. And that the specialists will construct appropriate career paths and support at least the initial steps of their implementation. (Hochman Musielak, 1994, Paszkowska Rogacz, 2004)

It would be desired, if young people were placed in schools in accordance with their interests and intellectual capabilities. The caregivers should think about it before making a decision concerning the choice of a secondary school, and prepare young people for a larger, but qualitatively different mental effort, encouraging their pupils in this process. In this course of actions, some of the specific personal, social and economic determinants should be taken into account. This 
requires a professionally prepared program for gaining self-reliance; a care, foster, and education program. And above all - a program that allows the construction of implementable career development paths. This cannot be done without the participation of a vocational counsellor.

Among the 87 foster care pupils who applied independently ${ }^{1}$ for participation in the aforementioned EQUAL Community Initiative:

- 37 wanted to participate in computer skill trainings (courses),

- 75 wanted to participate in language courses,

- 37 wanted to participate in vocational trainings,

- 18 (over 20\%) needed to go to an appointment in the Vocational and Social Counselling Office functioning within the project - according to the initial information, they needed to change theirs schools quickly.

It should be noticed that over $40 \%$ of the Project participants expressed the need for participating in additional vocational trainings. They were going to start their independent lives - but with what social and vocational competencies? Nobody offered them any ways of development, nor talked to them about their needs. The number of the ones who later took effective steps in order to fulfil those needs, is another question.

This data was collected at the beginning of the project, which started in 2005, and in the first half of 2007 only, the counselling office served 48 new clients who were given the opportunity to attend various professional courses.

Until the first half of June 2007, the vocational counsellors worked with over 200 pupils who received over 200 positive decisions concerning participation in professional courses, after attending specialist psychological tests.

It needs to be stated that these youths were able to use the chance of better preparation to entering the labour market, and starting independent lives, only thanks to the realised project. It provided consultations and assistance of the vocational counsellors, and financed the trainings - but are those needs not possible to fulfil without such support?

It is well known that finding vocational counsellors employed outside psychological counselling centres, or specialist and school career centres, is practically impossible. The tasks of vocational counsellors in the counselling centres are successfully fulfilled by the employed psychologists and pedagogues, but the number of School Career Centre is not very high. Schools are obliged to provide career guidance services that are performed by the employed pedagogues, psychologists, or trained teachers, who give lessons on entrepreneurship, for example. The role of the Voluntary Labour Corps also cannot be forgotten - with their Youth Employment Agencies, Youth Education and Labour Centres, and Mobile Centres for Career Information.

\footnotetext{
${ }^{1}$ Among over 110 pupils put up by the foster care institutions - data from the Initial Report on Project realisation
} 
Despite all that, no one offered our youth the vocational counselling services in the field of creating career path, nor the ways of achieving some of its steps.

It is obvious that if the vocational counselling system functioned well, even in its truncated form, this group of clients surely could have received the necessary support. The reason cannot be the lack of funds for vocational trainings - they can be financed from the Labour Fund (the law on employment promotion and labour market institutions) by the District Employment Agencies or the Voluntary Labour Corps.

Clearly, there is a need to ensure a well-organized and well-functioning system of vocational guidance aimed especially at disfavoured youth, including the pupils from the foster care and social rehabilitation institutions, and also foster families. The experience gained from the project clearly shows the need for a "special" support system for development of young people leaving care facilities, but also shows the specific difficulties of this group. Beyond doubt, the main hindrance in creating a universal system, even on a regional level, is the significantly different approach of the local government to the process gaining self-reliance. To a large extent, it results from various opportunities in finances, premises, and even in personal traits.

However, regardless of the form of gaining self-reliance, young people start their independent lives completely unprepared. They do not know how to manage reasonably their marginal financial resources, possess little knowledge on rational nutrition, and sometimes, despite large facilities, they are unable to cope in the social infrastructure that was created for them, too, after all.

The experience gained during the realisation of the project allowed creating the concept of Development Support Centre - an integrated model of introducing the disfavoured youth into the labour market.

\section{Development Support Centre}

Development Support Centre should be an institution harmonising and integrating a variety of activities aimed at supporting the professional development and the process of entering into the labour market of the children's homes pupils and other groups of young people at risk of social exclusion, facilitating the understanding of mechanisms and requirements of the modern labour market, conducting introductory vocational orientation, and allowing the acquiring of the necessary social competencies.

In the course of the activity hitherto, no forms of cooperation between institutions dealing with the disadvantaged youth, and other institutions, such as aid, education, employment services and employers, were created. The organizations representing young people have not yet developed any effective ways of shaping 
the personal, educational, and professional paths, the education, or the ways of cooperation with the local labour market institutions (voivodeship employment agencies, district employment agencies, training providers, employers). Young people often lack support in choosing the path of personal and professional development, and do not possess the experience enabling them to benefit form the available training, educational, and professional offers. They lack the skills of job seeking, employment conditions, career choice, and recruitment procedures (selfpresentation, writing resumes and cover letters).

Moreover, the environment of employers, employment services (voivodeship and district employment agencies), and the local government, has not created a model of systematic support for social activities and projects, and has limited itself mainly to a quite rare support of the companies during charitable and social events - not involving them in the creation of lasting effects of mutual cooperation. There is no support system for long-term activities of the socially responsible companies created by the local employment offices, and other elements of social infrastructure, possessing the aid measures that can contribute to the construction of a social partnership and to the support of disfavoured groups in the labour market.

Moreover, there is a lack of a place, a common platform for the exchange of information; a lack of an integrated system for the collection of information among the partners from the local labour market; a lack of information on lives of the self-reliant pupils from children's homes and other foster care institutions. There is a chaos of information; there is no coherent system for exchange of information, which leads to a lack of an integrated influence of various institutions supporting this social category of the disfavoured group.

Our proposition gives a chance to eliminate at least some of the mentioned problems.

The most meaningful would be the activities of Development Support Centre oriented towards:

- the permanent care of social and career guidance,

- the possibility of responding directly in the process of gaining self-reliance by young people, through flexible and professionally selected instruments of vocational training,

- supporting the self-reliance gaining process from the moment the pupils come to the children's home or another form of foster care,

- the use of mentoring as one of the basic tools of career guidance - and also of a separate, independent (autonomous) method of supporting the self-reliance gaining processes at the same time.

The proposed Development Support Centre model, which would work in the structures of social aid, will give a chance to provide comprehensive support for young people from disfavoured groups and at the risk of social exclusion, and the organizations representing them in the construction of individual paths of 
professional and personal development. These actions will create more favourable conditions for making and implementing decisions related to the process of gaining self-reliance and adapting to society.

The assumed effects of the Development Support Centre's activity towards youth were:

- reinforcement of the self-reliance gaining process,

- increasing the chances of finding employment,

- improved life and vocational orientation of the pupils,

- joining various forms of aid within a single institution (easier accessibility),

- permanent and multi-dimensional support, not incidental.

The effects of the Development Support Centre's activity towards the system will be:

- integration of the various entities from the local labour market in dealing with specific issues of the local community (a network of employers, local government organisations, NGOs, public administration, universities, educational and training institutions, other stakeholders);

- improvement of the communication system, information flow, and data collection, through the use of a modern web-based platform;

- increased efficiency of the activities carried out for the benefit of the target group by the social and economic institutions through integrating the support and communication system;

- development and increased flexibility of the existing social care through the creation of a new professional structure;

- a support system for the employers in the process of realising the idea of social responsibility, implemented in a sustainable, not incidental manner;

- a monitoring system of the pupils' lives, and of the effectiveness of taken actions, basing on accepted indicators.

Unfortunately, the situation today is as follows:

- In early December 2011, the Centre for Immaterial Support (a part of the Social Welfare Centre in Lodz) will be replaced with the Centre for Social Integration as a part of the reorganisation of social care. Some of the objectives and planned tasks are similar, but have different range - and also some significantly different guidelines. In our plans, it is the social care that was supposed to be, through the mentioned centre, an animator, and partially a sponsor, of the basic activity - including initiation of mentoring. One of the conclusions, developed mainly in the last project, was a proposal of paid mentoring - withdrawing from the use of volunteering only, and commissioning mentoring, for example, under civil law contracts. The contracts seem to increase the possibility of supervising the mentors, and the rules concerning the three participants of this project are also clearer. If there is no possibility of financing mentoring in this way - the only remaining option is to continue using the voluntary service with all of its advantages and disadvantages. 
- A comparison of the two approaches to mentoring (peer mentoring, implemented by the autonomous structures of Mentoring Office, and mentoring, applied in the last project) clearly highlights another difference (which was stressed weakly earlier) - the mentoring implemented in the EQUAL Initiative, and in the next project, by peer mentors working in the Mentoring Office, was based on the activity of this office - peer mentors were sharing the information among the pupils from social care institutions in Lodz and in the voivodeship, and supporting the interested colleagues. In the third project, mentoring was implemented as a recommendation of the counselling office - as a result of the carried out diagnostic and counselling activities, which was also one of the reasons for postulating the introduction of paid mentoring.

- The Voivodeship Labour Office in Lodz assessed our continued support towards the self-reliance gaining processes as not meeting the objectives of innovation, and refused to continue to support (co-finance) them. At the same time, in other parts of the country (for example, in Podlasie and Zachodniopomorskie Voivodeship), the first steps in using mentoring are currently funded under the Human Capital Programme. It might be a Polish specificity.

Despite this, the Development Support Centre team will continue its activities. It was mentioned earlier that some of the trained mentors have not stopped their activity - they continue to support their pupils. It is also planned to start commercial diagnostic and counselling activities, and to finance the processes of gaining self-reliance with the incomes. We will also share our experiences and support the development of the family assistant services, working for the promotion of this form of social work.

\section{References}

Clautterbuck D. (1998). Learning Alliances. London: IPD.

Czerepaniak-Walczak M. (2001). Doradztwo w reformowanej szkole- gimnazjum jako ośrodek doradztwa. [In:] WojtasikB.. Podejmowanie decyzji zawodowej przez młodzień i osoby doroste $w$ nowej rzeczywistości społeczno-politycznej. Wrocław.

Gaś Z. B. (2000). Psychoprofilaktyka. Lublin: Wydawnictwo UMCS.

Grubb W. Norton. (2002). Who Am J: The inadequacy of career information in The Information Age. August OECD.

Grubb W. Horton J. (2005). Praca $w$ harmonii, [In:] Metody pracy z młodzieża, collective work. Dolnośląskie Centrum Informacji Zawodowej i Doskonalenia Nauczycieli w Wałbrzychu i WMZDZ w Olszynie.

Grubb W. N. (2002). An Occupation in Harmony. The roles of markets ang governmantsin ceareer information and career guidance. September OECD.

Hochman Musielak M. (1994). Pozycja doradcy zawodowego w rejonowym urzędzie pracy. Zeszyty informacyjno metodyczne doradcy zawodowego. MGPiPS.

Janicz J, Szyktanc Ciekańska A. (2007). Rola doradcy zawodowego w pracy z dzieckiem z potrzeba kształcenia specjalnego w placówce opiekuńczo-wychowawczej. [In:] Skłodowski H. (Ed.). Mentoring w doradztwie zawodowym. Łodzi: SWSPiZ 
Kargulowa A (2005). Zmiany tożsamości poradnictwa zawodowego i ich reperkusje. Katowice.

Krawiec M. (2008). Centrum Wspierania Rozwoju, [In:] Skłodowski H. (Ed.). Polskie doradztwo dla młodzieży - idea czy rzeczywistość. Łódź: SWSPiZ.

Krawiec M. (2007). Mentoring jako podstawa założeń wychowawczych i organizacyjnych drugiego obozu EQUAL. [In:] Skłodowski H. (Ed.). Mentoring w doradztwie zawodowym. Łodzi: SWSPiZ.

Małecka A. (2005). Doradztwo zawodowe w procesie kreowania indywidualnej ścieżki kariery zawodowej. www.doradca-zawodowy.pl [20.10.2012]

Metody Pracy z Młodzieżą. Collective work., Dolnośląskie Centrum Informacji Zawodowej i Doskonalenia Nauczycieli w Wałbrzychu., Warmińsko-Mazurski Zakład Doskonalenia Zawodowego w Olsztynie. Warszawa.

Moroz A, Popławska E. (2006). Pierwszy krok do samodzielności. [In:] Skłodowski H (Ed.) Wspótczesny paradygmat doradztwa zawodowego. SWSPiZ: Wydawnictwo.

Parasole E., Wray M. (2002). Trener i mentor. Kraków: Oficyna Ekonomiczna.

Parsole E. (1998). Coaching i mentoring. Warszawa: Wydawnictwo PETIT.

Paszkowska Rogacz A, Tarkowska M. (2004). Metody pracy z grupa w poradnictwie zawodowym. Warszawa: KOWEZIU.

Paszkowska Rogacz A. (2007). Profil kompetencji doradcy zawodowego. [In]: H. Skłodowski (Ed.) Mentoring $w$ doradztwie zawodowym. Studia i Monografie. Społeczna Wyższa Szkoła Przedsiębiorczości i Zarządzania w Łodzi,.

Sołtys A., Piekarska A. (2007). "Mentoring i coaching jako alternatywna forma wzmacniania działań społecznych i instytucjonalnych, [In]: Skłodowski H., (Ed.). Mentoring w doradztwie zawodowym. Studia i Monografie. Łódź: SWSPiZ,.

Sołtys A., Tarkowska M. (2008). Mentoring w praktyce. Ścieżka kształcenia mentorów i peer mentorów dla grup defaworyzowanych. Łódź: SWSPiZ.

Szymańska J., (2000). Programy profilaktyczne. Podstawy profesjonalnej profilaktyki. Warszaw: CMPPP MEN.

Ustawa z dnia 12.03.2004 o pomocy społecznej. Dz.U. z dnia 15.04.2004 nr 64 pozycja 593

Ustawa z dnia 20.04.2004 o promocji zatrudnienia $i$ instytucjach rynku pracy. Dz.U. z dnia 01.05.2004 nr 99 poz. 1001 i Dz.U 2005 nr 164 poz. 1366

http://www.cabinetoffice.gov.uk/third_sector/ [20.10.2012]

http://www.coachingnetwork.org.uk/ResourceCentre/Links/CoachingTraining.htm [20.10.2012]

http://www.mentors.ca/mentorwks.html [20.10.2012] 